\title{
Immunoblot analysis of human IgM, IgG and IgA responses to plasmid-encoded antigens of Yersinia enterocolitica serovar $\mathrm{O} 3$
}

\author{
T. H. STÅHLBERG, KAISA GRANFORS and AULI TOIVANEN*
}

Departments of Medical Microbiology and "Medicine, Turku University, SF-20520 Turku 52, Finland

\begin{abstract}
Summary. Human IgM, IgG and IgA responses after infection with Yersinia enterocolitica serovar $\mathrm{O} 3$ were studied by immunoblotting sera against whole-cell homogenates of a plasmid-containing strain of $Y$. enterocolitica $\mathrm{O} 3$ and a plasmid-free strain derived from it; each strain was grown in conditions expressive for the plasmid. The antibodies observed were directed against several plasmid-encoded polypeptides. The response against different bacterial components decreased uniformly with time and the persisting antibody production was directed against several epitopes. Strong reactions to the prominent plasmid-specified antigens of mol. wts $\left(10^{3}\right) 26,34,45$ and 52.5 were found more often with IgG-class antibodies than with $\operatorname{IgM}$ or IgA; the latter immunoglobulins recognised, respectively, antigens of mol. wt $\left(10^{3}\right) 26$ and 45 (IgM) and 26, 34 and 52.5 (IgA). Immunoblotting of sera from patients with yersiniatriggered reactive arthritis did not reveal any antigens that were involved additionally or specifically. However, IgA-mediated recognition of certain antigens of mol. wts $\left(10^{3}\right) 26,34$ and $52 \cdot 5$ tended to persist longer in the arthritic patients.
\end{abstract}

\section{Introduction}

The virulence of Yersinia enterocolitica, Y. pseudotuberculosis and $Y$. pestis is clearly associated with plasmids of mol. wt $\left(10^{6}\right) 40-45$ that are known to encode several polypeptides (Martinez, 1983; Heesemann et al., 1984; Portnoy et al., 1984; Bölin et al., 1985; Mazza et al., 1985; Skurnik, 1985). Studies of the immune responses against plasmidencoded antigens, however, have been restricted to immunised animals or to the IgG responses of a limited number of patients (Martinez, 1983; Mazza et al., 1985; Skurnik, 1985).

Among yersiniae, $Y$. enterocolitica serovar $\mathrm{O} 3$ is the most important enteropathogen in Scandinavian countries. When, previously, the immune response against chromosomally coded antigens of this bacterium was studied by immunoblotting of sequentially collected patients' sera, it appeared that more or less the same antigens were recognised by all immunoglobulin classes. Antigens recognised early or late in the course of infection were essentially the same and the responses to the individual antigens decreased uniformly with time; this suggested that the total antigenic repertoire of the bacterium was responsible for persisting antibody production (Toivanen et al., 1985).

Received 18 Aug. 1986; revised version accepted 18 Nov. 1986.
Despite some contradictory reports (Mazigh et al., 1985; Simonet et al., 1985), it is well-established that the plasmid-specified proteins are important for the virulence of yersiniae (Zink et al., 1980; Heesemann et al., 1983 and 1984; Portnoy et al., 1984; Bölin et al., 1985; Portnoy and Martinez, 1985). We considered it important, therefore, to study which of the plasmid-encoded proteins were antigenic during natural infection in man and how the proteins were recognised by antibodies of different immunoglobulin classes. Furthermore, we wished to clarify whether the early and late responses were directed against different antigens. Accordingly, sera obtained from patients in the acute or convalescent stages of infection (0-2 and 10-12 months, respectively, after onset of infection) were immunoblotted against a plasmid-containing strain of $Y$. enterocolitica serovar $\mathrm{O} 3$ and a plasmidcured strain derived from it, with both strains grown in conditions favouring plasmid expression.

\section{Materials and methods \\ Patients \\ A diagnosis of infection by $Y$. enterocolitica serovar $\mathrm{O} 3$ was established by bacterial isolation, or serologically with a serotype-specific enzyme-linked immunosorbent}


assay (ELISA) (Granfors, 1979) or both. The clinical features of the 16 patients included are summarised in table I. The average age (SD) of the non-arthritic patients was 37 (13) years and of the arthritic patients was 44 (13) years. Specimens of serum, obtained from patients $0-2$ months and 10-12 months after onset of the infection, were stored at $-20^{\circ} \mathrm{C}$. A further six specimens of serum from uninfected persons without a history of yersiniosis were studied as controls.

\section{Rabbit antiserum against Y. enterocolitica serovar $\mathrm{O3}$}

This serum, kindly supplied by Dr $\mathbf{H}$. Wolf-Watz, Umeå, Sweden, was raised by immunising a rabbit with a live plasmid-containing strain of $Y$. enterocolitica serovar O3, grown in conditions that allow plasmid expression. Three injections, each containing $10^{8}$ bacteria, were given intravenously at 2 -week intervals. The rabbit was bled 4 days after the final injection.

\section{Bacterial strains and cultural conditions}

Strain 4147 of $Y$. enterocolitica serovar O3, an isolate from the faeces of a patient who developed reactive arthritis following infection, contains a virulence-associated plasmid (type II of Pulkkinen et al., 1986) designated hereafter as pYV + (plasmid of Yersinia, associated with virulence). A plasmid-cured derivative strain $\mathrm{pYV}$ - was obtained from single colonies growing at $37^{\circ} \mathrm{C}$ on the magnesium oxalate-containing agar medium of Higuchi and Smith (1961). The presence or absence of virulence plasmid was verified by an autoagglutination test (Laird and Cavanaugh, 1980) and by plasmid purification (Pulkkinen et al., 1986). Stock cultures were maintained at $-70^{\circ} \mathrm{C}$ in Trypticase Soy Broth (Difco) containing glycerol $20 \% \mathrm{v} / \mathrm{v}$. For optimal expression of the plasmidspecified polypeptides, the following procedure (Dr H. Wolf-Watz, personal communication) was used : bacteria were grown overnight at room temperature in Nutrient Broth (Oxoid); pelleted bacteria were resuspended in a small amount of saline $(\mathrm{NaCl}, 0.9 \% \mathrm{w} / \mathrm{v})$ and inoculated in Higuchi Minimal Medium supplemented with Tryptone (Difco) $1 \% \mathrm{w} / \mathrm{v}$, Yeast Extract (Oxoid) $0.5 \% \mathrm{w} / \mathrm{v}$ and glucose $0.2 \% \mathrm{w} / \mathrm{v}$; cultures were incubated with shaking $(250 \mathrm{rpm})$ at $37^{\circ} \mathrm{C}$ to an optical density of 0.3 at $540 \mathrm{~nm}$; bacteria were washed twice in phosphate-buffered saline

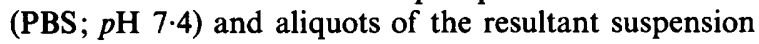
were centrifuged in an Eppendorf centrifuge for $10 \mathrm{~min}$; the pellets obtained were stored at $-20^{\circ} \mathrm{C}$ until required.

\section{SDS-PAGE and immunoblotting}

The bacterial pellet was suspended in sample buffer $(0.06 \mathrm{M}$ Tris-HCl, $p \mathrm{H} 6 \cdot 8)$ containing glycerol $10 \% \mathrm{w} / \mathrm{v}$, sodium-dodecyl sulphate $5 \% \mathrm{w} / \mathrm{v}$ and 2 -mercaptoethanol $5 \% \mathrm{v} / \mathrm{v}$, and boiled for $5 \mathrm{~min}$. Disrupted sample preparations were separated on a vertical sodiumdodecyl sulphate polyacrylamide-slab gel (SDS-PAGE) (Laemmli, 1970), with a stacking gel of acrylamide $5 \%$

Table I. Clinical features of the patients*

\begin{tabular}{|c|c|c|c|c|c|c|c|c|c|}
\hline \multirow[b]{2}{*}{$\begin{array}{c}\text { Patient } \\
\text { no. }\end{array}$} & \multirow[b]{2}{*}{$\begin{array}{c}\text { Age } \\
\text { (y) }\end{array}$} & \multirow[b]{2}{*}{ Sex } & \multirow[b]{2}{*}{ HLA-B27 } & \multirow[b]{2}{*}{$\begin{array}{l}\text { Bacterial } \\
\text { isolation } \dagger\end{array}$} & \multicolumn{5}{|c|}{ Clinical symptoms } \\
\hline & & & & & $\begin{array}{c}\text { Abdominal } \\
\text { pain }\end{array}$ & Diarrhoea & Arthritis $\ddagger$ & $\begin{array}{c}\text { Other } \\
\text { sequelae }\end{array}$ & $\begin{array}{l}\text { Highest ESR } \\
\text { value }(\mathrm{mm} / \mathrm{h})\end{array}$ \\
\hline 1 & 17 & $\mathbf{M}$ & - & - & + & - & - & - & 80 \\
\hline 2 & 25 & $\mathbf{M}$ & - & - & + & + & - & - & 46 \\
\hline 3 & 28 & $\mathbf{F}$ & - & - & + & + & - & - & 12 \\
\hline 4 & 31 & $\mathbf{F}$ & - & + & + & + & - & - & $\ldots$ \\
\hline 5 & 35 & $\mathbf{M}$ & + & + & + & - & - & - & 91 \\
\hline 6 & 38 & $\mathrm{~F}$ & - & + & + & + & - & - & 64 \\
\hline 7 & 49 & $\mathrm{~F}$ & - & - & + & + & - & - & 24 \\
\hline 8 & 57 & $\mathrm{~F}$ & - & - & - & + & - & - & 59 \\
\hline 9 & 32 & $\mathbf{M}$ & - & + & - & - & + & - & 13 \\
\hline 10 & 36 & $\mathrm{~F}$ & + & + & + & + & + & - & 45 \\
\hline 11 & 37 & M & - & - & + & + & + & - & 64 \\
\hline 12 & 39 & $\mathbf{M}$ & + & + & + & + & + & - & 66 \\
\hline 13 & 56 & $\mathbf{M}$ & + & - & + & - & + & Iritis & 27 \\
\hline 14 & 56 & $\mathbf{M}$ & + & - & + & + & + & - & 30 \\
\hline 15 & 56 & $\mathbf{M}$ & + & - & + & + & + & - & 23 \\
\hline 16 & 65 & $\mathrm{~F}$ & - & - & - & + & + & - & 59 \\
\hline
\end{tabular}

* All patients showed a clear response in terms of specific IgM-, IgG- or IgA-class antibodies against Y. enterocolitica O3 as detected by ELISA.

+ Y. enterocolitica serovar $\mathrm{O} 3$ was $(+)$, or was not $(-)$, isolated.

$\ddagger$ Definite synovitis, confirmed by a physician, was $(+)$, or was not $(-)$, present. 
and a resolving gradient gel of $10-12.5 \%$. Standards of known mol. wt were included in each gel run (Electrophoresis Low Molecular Weight Calibration Kit, Pharmacia Fine Chemicals AB, Uppsala, Sweden). Bromophenol Blue was used as the tracking dye. Proteins were usually visualised with Coomassie Brilliant Blue $\mathbf{R}$ 250 , although some gels were silver stained with a commercially available system (Bio-Rad Silver Stain, Bio-Rad Laboratories, Richmond, CA, USA).

Immunoblotting was performed by a modification of the method of Towbin et al. (1979). After electrophoresis, gels were transferred immediately to the electrotransfer apparatus (Transphor, LKB-Bromma, Bromma, Sweden). The separated components were transferred to nitrocellulose sheets (HAHY 00100 , pore size $0.45 \mu \mathrm{m}$, Millipore SA, France) in pre-chilled Tris-glycine buffer $(p \mathrm{H} 8.3)$, at $1.0 \mathrm{~A}$ for $1.5 \mathrm{~h}$. Non-specific binding sites were blocked by overnight incubation at $4^{\circ} \mathrm{C}$ of the nitrocellulose sheet in PBS ( $p \mathrm{H} \mathrm{7.4)}$ containing horse serum $10 \% \mathrm{v} / \mathrm{v}$ (HS-PBS). After five washes with PBS, the sheets were cut into vertical strips and allowed to react overnight at $4^{\circ} \mathrm{C}$ with a 1 in 100 dilution of patient's serum in HS-PBS. The strips were washed as before and incubated for $3 \mathrm{~h}$ at room temperature with horseradish peroxidase-labelled rabbit anti-human $\operatorname{IgM}, \operatorname{IgG}$ or $\operatorname{IgA}$, specific for heavy chains (DAKO Immunoglobulins, Copenhagen, Denmark), and diluted in HS-PBS to 1 in 1500,1 in 1000 , and 1 in 1500 , respectively. After three washes, the strips were developed with 4-chloro-1naphthol (Sigma, St Louis, MO, USA) according to the method of Hawkes et al. (1982).

Immunoblotting of the rabbit antiserum against $Y$. enterocolitica $\mathrm{O} 3$ was performed in the same way. The rabbit serum was diluted 1 in 300 , and the peroxidaseconjugated swine immunoglobulins to rabbit immunoglobulins (DAKO Immunoglobulins) were diluted 1 in 1000 , in HS-PBS.

\section{HLA typing}

The HLA-B27 lymphocyte antigen was determined by a cytotoxicity method with Histognost ${ }^{\circledR}$-B27 (Behring Institut, Marburg, FRG).

\section{Results}

\section{Demonstration of plasmid-encoded antigens}

The presence of a virulence-associated plasmid in strain pYV + of $Y$. enterocolitica serovar $\mathrm{O} 3$ was established by the autoagglutination test and by plasmid purification. The plasmid-free strain pYV - derived from it by differential growth on magnesium-oxalate agar at $37^{\circ} \mathrm{C}$ was not autoagglutinable and plasmids were no longer detectable on purification. The presence or absence of plasmidspecified antigens was always confirmed by autoag- glutination. As a further control, the major polypeptides from whole-cell lysates of strains $\mathrm{pYV}+$ and pYV - were separated by SDS-PAGE and stained by Coomassie Brilliant Blue. A major band of mol. wt 150000 was observed in strain pYV + only (data not shown).

When a rabbit antiserum raised against $Y$. enterocolitica serovar $\mathrm{O} 3$ was immunoblotted against both plasmid-containing and plasmid-free strains grown at $37^{\circ} \mathrm{C}$, several plasmid-specified antigens were recognised (fig. 1); the most prominent of these were of mol. wts $\left(10^{3}\right): 12 \cdot 5,22,26$, $32,34,38,45,49,52 \cdot 5$ and 150 . In addition, the

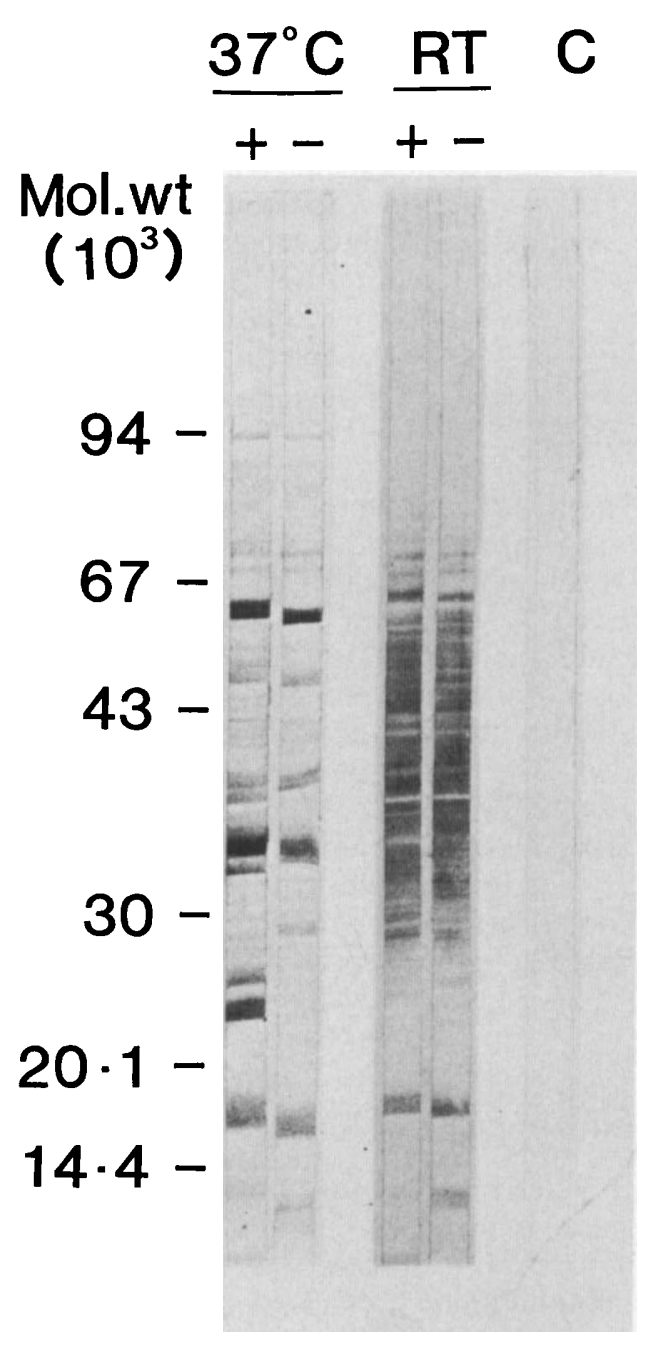

Fig. 1. Immunoblot analysis of rabbit antiserum raised against $Y$. enterocolitica $\mathrm{O} 3$ in tests with strain $\mathrm{pYV}+$ of $Y$. enterocolitica that contained plasmid $(+)$ or strain $\mathrm{pYV}$ - that was plasmidfree (-). Bacteria were grown at $37^{\circ} \mathrm{C}$ or at room temperature (RT). $\mathrm{C}=$ control serum from a non-immunised rabbit in tests with strain $\mathrm{pYV}+$. 
following minor antigens were detected of mol. wts $\left(10^{3}\right): 40,42,70$ and 80 . Altogether, at least 14 plasmid-specified antigens were observed. It was of interest that an antigen of mol.wt 28000 was apparently present in the plasmid-cured strain only. These differences were not found when the plasmidcontaining and plasmid-free strains were grown at room temperature.

\section{IgM and $\operatorname{Ig} A$ antibodies}

From each of 16 patients with yersinia infection, sera were obtained 0-2 and 10-12 months after onset of infection. By immunoblotting these 32 sera against strains $\mathrm{pYV}+$ and $\mathrm{pYV}-$ of $Y$. enterocolitica serovar $\mathrm{O} 3$, IgM- and IgA-class antibodies against plasmid-specified antigens were recognised. IgM-class antibodies of several patients reacted with the plasmid-specified antigens of mol. wts $\left(10^{3}\right) 26$ and 45 . $\operatorname{IgA}$ immunoglobulins recognised at least those antigens of mol. wts $\left(10^{3}\right) 26,34$ and $52 \cdot 5$.

\section{IgG antibodies}

All patients had detectable levels of IgG antibodies to several antigenic determinants of both the pYV + and pYV - strains, as illustrated in fig. 2, whereas the sera from the healthy controls responded to neither strain. There was considerable heterogeneity in the reactions obtained with individual sera with about 15 major and 20 minor bands revealed. The most pronounced bands were those of mol. wts $\left(10^{3}\right) 14,28,33,35,50$ and 67 , present in both plasmid-containing and plasmid-free strains. The immunoblot pattern against the plasmid-containing strain showed a few other bands, the most strongly reacting of which had mol. wts $\left(10^{3}\right)$ of $26,34,45$ and $52 \cdot 5$.

\section{Comparison of $\operatorname{Ig} M, \operatorname{Ig} G$ and $\operatorname{Ig} A$ responses}

The different immunoglobulin classes generally recognised more or less the same antigens. IgM and IgA patterns were much weaker than those for IgG, and the total amount of visible IgM or IgA bands could not be counted because of intense background staining. As well as some weaker bands, the prominent plasmid-specified antigens - of mol. wts $\left(10^{3}\right) 26,34,45$ and $52 \cdot 5$-were recognised more frequently by $\operatorname{IgG}$ than by $\operatorname{IgM}$ or $\operatorname{IgA}$; the latter immunoglobulins recognised, respectively, anti-

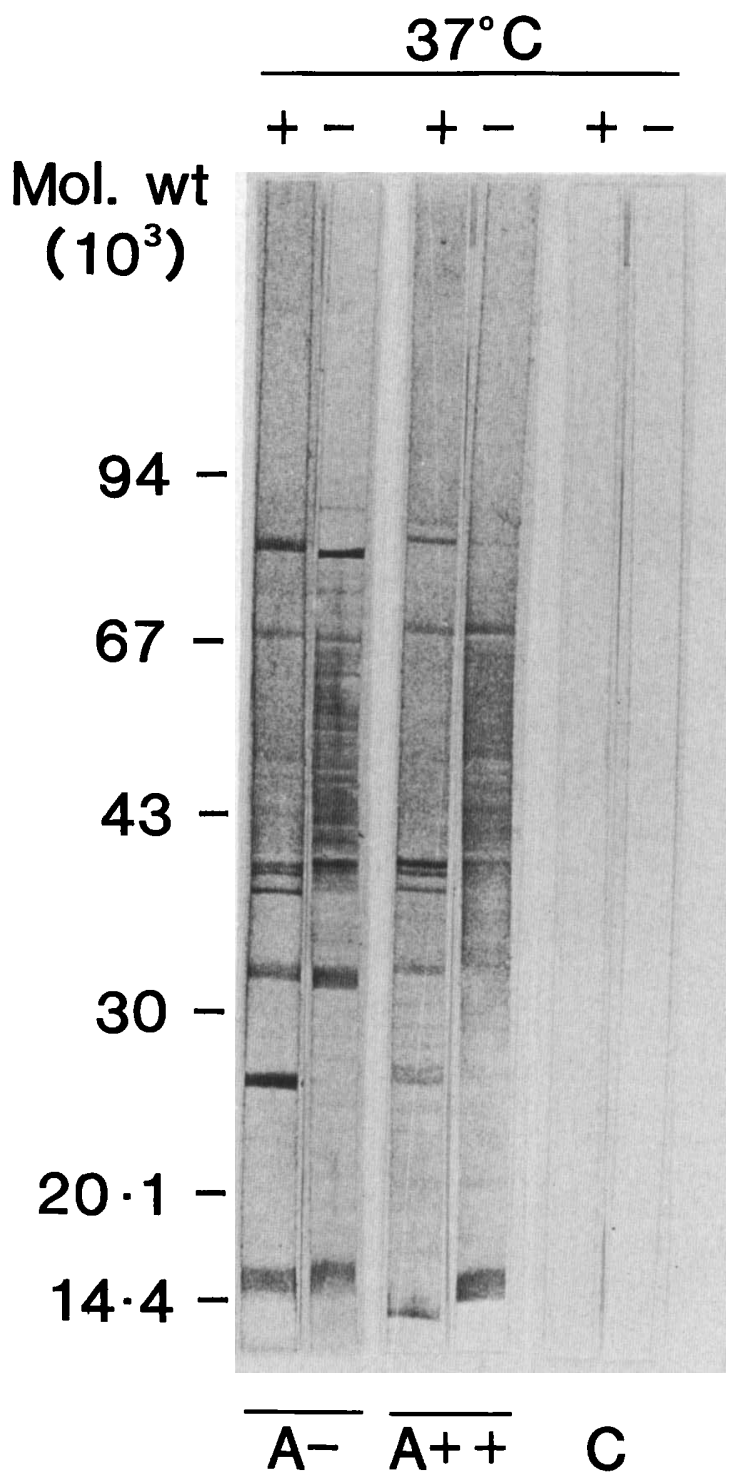

Fig. 2. Immunoblot analysis showing IgG responses against strains of $Y$. enterocolitica 03 . Strain pYV + contained plasmid $(+)$; strain pYV - did not $(-)$. Sera were from: a patient with uncomplicated yersiniosis, $\mathrm{A}-$; a patient with reactive arthritis, $\mathrm{A}++;$ a healthy control, $\mathrm{C}$.

gens of mol. wts $\left(10^{3}\right) 26$ and 45, and 26, 34 and $52 \cdot 5$ (table II).

\section{Comparison of early and late responses}

The same antigens were recognised in tests with acute and convalescent sera. It was the strength of the reactions only that varied; thus IgM showed a few, faint bands with convalescent sera whereas IgG- and IgA-reactive bands generally appeared to be quite strong at that same stage. 
Table II. Reactions of different immunoglobulins with plasmid-encoded antigens of $Y$. enterocolitica serovar $\mathrm{O} 3$ in tests with sera from non-arthritic and arthritic patients

\begin{tabular}{|c|c|c|c|c|c|c|c|c|c|}
\hline \multirow{3}{*}{$\begin{array}{l}\text { Immuno- } \\
\text { globulin } \\
\text { isotype }\end{array}$} & \multirow{3}{*}{$\begin{array}{l}\text { Arthritis in } \\
\text { patient }\end{array}$} & \multicolumn{8}{|c|}{$\begin{array}{l}\text { Number of sera (of } 8 \text { tested) from acute (A) or convalescen } \\
\text { (C) stages of infection }{ }^{*} \text { that reacted with plasmid-encode } \\
\text { antigens of } Y \text {. enterocolitica of mol. wt }\left(10^{3}\right)\end{array}$} \\
\hline & & \multicolumn{2}{|c|}{26} & \multicolumn{2}{|c|}{34} & \multicolumn{2}{|c|}{45} & \multicolumn{2}{|c|}{52.5} \\
\hline & & A & C & A & C & $\mathbf{A}$ & $\mathrm{C}$ & A & $\mathrm{C}$ \\
\hline IgM & $\bar{t}$ & $\begin{array}{l}6 \\
4\end{array}$ & $\begin{array}{l}3 \\
1\end{array}$ & $\begin{array}{l}\text { ND } \\
\text { ND }\end{array}$ & $\begin{array}{l}\text { ND } \\
\text { ND }\end{array}$ & $\begin{array}{l}6 \\
4\end{array}$ & $\begin{array}{l}4 \\
2\end{array}$ & $\begin{array}{l}\text { ND } \\
\text { ND }\end{array}$ & $\begin{array}{l}\text { ND } \\
\text { ND }\end{array}$ \\
\hline $\operatorname{IgG}$ & $\overline{+}$ & $\begin{array}{l}5 \\
6\end{array}$ & $\begin{array}{l}2 \\
2\end{array}$ & $\begin{array}{l}6 \\
5\end{array}$ & $\begin{array}{l}1 \\
2\end{array}$ & $\begin{array}{l}7 \\
6\end{array}$ & $\begin{array}{l}3 \\
4\end{array}$ & $\begin{array}{l}5 \\
6\end{array}$ & $\begin{array}{l}0 \\
4\end{array}$ \\
\hline $\operatorname{Ig} A$ & - & $\begin{array}{l}4 \\
4\end{array}$ & $\begin{array}{l}0 \\
4\end{array}$ & $\begin{array}{l}5 \\
7\end{array}$ & $\begin{array}{l}1 \\
4\end{array}$ & $\begin{array}{l}\text { ND } \\
\text { ND }\end{array}$ & $\begin{array}{l}\text { ND } \\
\text { ND }\end{array}$ & $\begin{array}{l}5 \\
5\end{array}$ & $\begin{array}{l}1 \\
4\end{array}$ \\
\hline
\end{tabular}

$\mathrm{ND}=$ not detected.

* Sera were obtained 0-2 months (A) or 10-12 months (C) after onset of infection.

\section{Comparison of sera from non-arthritic and arthritic patients}

The qualitative responses with sera from nonarthritic and arthritic patients were directed in the same way against the individual antigens and there was no antigen, plasmid-specified or otherwise, that was exclusively detected with sera from either patient group. In an example presented in fig. 2, two antigens, the mol. wts of which were 88000 and 92000 were recognised exclusively with sera from arthritic or non-arthritic patients, respectively; these differences, however, were not consistent when complete groups of patients were compared. When individual bands were compared, it was obvious that their recognition with sera from the two patient groups was remarkably similar. A similar conclusion was reached when the bands were grouped and counted according to their mol. wts, as shown for IgG (fig. 3). The mean number of visible IgG bands was the same for sera from non-arthritic and arthritic groups: 34.8 (SEM 4.6) and 34.8 (SEM 5.2) at 1-2 months after onset of the infection, and 23.4 (SEM 5.3) and 23.5 (SEM $5 \cdot 1)$ at $10-12$ months, respectively. The only difference observed was that plasmid-encoded antigens of mol. wts $\left(10^{3}\right) 26,34$ and 52.5 were more often recognised by the sera from arthritic than non-arthritic patients at 10-12 months after onset of the infection; the difference was, however, small and applied to IgA-class antibodies only (table II).

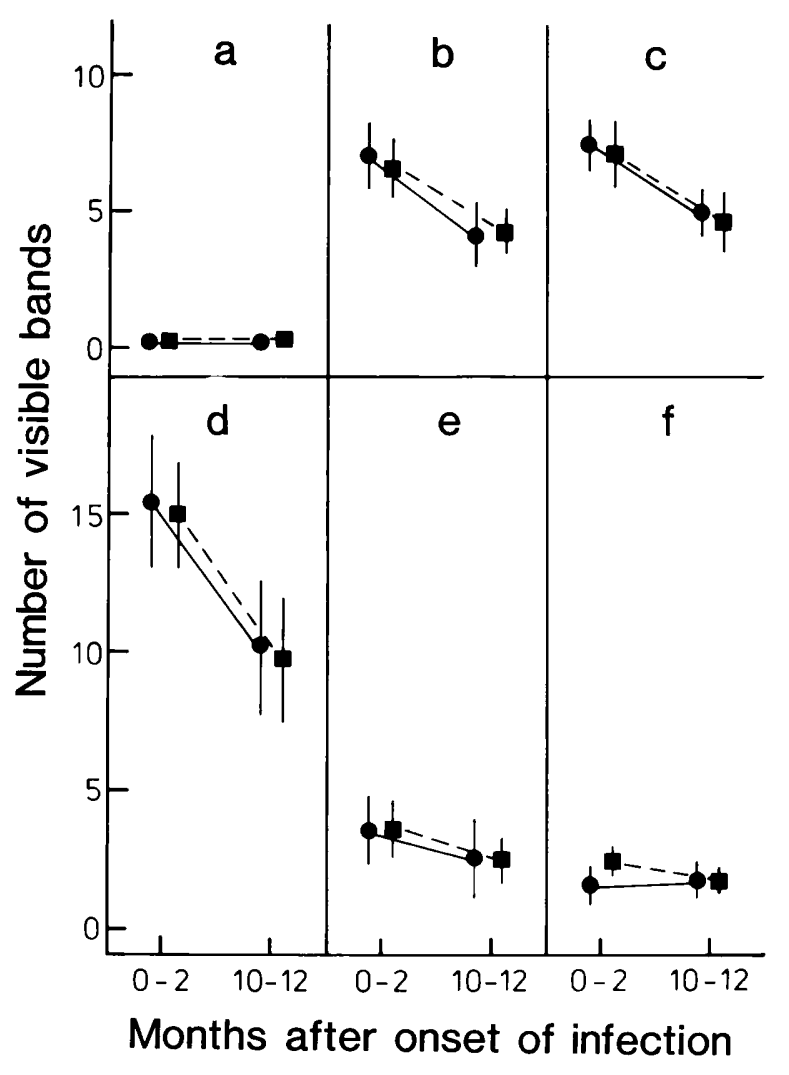

Fig. 3. IgG response (mean number of visible bands of different mol. wt) in sera of patients with uncomplicated yersiniosis $(\square---\square)$ or with Yersinia-triggered reactive arthritis $(\bullet-\bullet)$. Number of sera per group at each time point was 8 ; bar $= \pm$ SEM. Mol. wts $\left(10^{3}\right)$ of bands were: (a) $>94$, (b) 67-94, (c) 43-67, (d) 30-43, (e) 20·1-30, (f) $<20$. 


\section{Discussion}

In the present study, immunoblotting was applied to compare IgM-, IgG- and IgA-responses against the plasmid-encoded antigens of $Y$. enterocolitica serovar $\mathrm{O} 3$ after natural infection in man. The results obtained indicated that the antibody response was directed against several individual antigens, that different immunoglobulin classes recognised the different antigens similarly and that antibodies against the different antigens decreased uniformly with time. The IgA-response against some of the plasmid-specified antigens seemed to persist longer in arthritic than in non-arthritic patients.

The immunoblot patterns revealed that the expression of the antigens of $Y$. enterocolitica was influenced not only by the presence or absence of the virulence plasmid but also by growth temperature. Thus, several antigens were absent when the plasmid-containing $\mathrm{pYV}+$ strain was grown at $37^{\circ} \mathrm{C}$. Again, this phenomenon may depend on factors other than plasmid expression because a partial transition from smooth to rough lipopolysaccharides has been shown to occur at higher temperatures (Darveau et al., 1983; Kawaoka et al., 1983; Ogasawara et al., 1985).

Recognition of the plasmid-encoded antigens was achieved by comparison of results with related plasmid-containing and plasmid free strains. First, only one prominent plasmid-encoded band could be detected by SDS-PAGE. Although this method is far less sensitive than immunoblotting, it provided, nevertheless, an appropriate control because it is known that all of the major plasmid-specified outer-membrane proteins are expressed in similar conditions (Portnoy et al., 1984; Bölin et al., 1985). Second, by immunoblotting a yersinia-specific rabbit antiserum against both strains, at least 14 plasmid-encoded antigens were revealed, a finding in agreement with that of Portnoy et al. (1984) who detected $\geqslant 20$ plasmid-specified polypeptides by SDS-PAGE and autoradiography after plasmids of yersiniae were transformed into minicell-producing Escherichia coli. Again, Skurnik (1985) by immunoblotting rabbit anti-yersinia serum found $\geqslant 16$ polypeptides apparently associated with the virulence plasmid; the mol. wt distribution of the bands was similar to that found in the present study. Perhaps because of varying growth conditions, fewer plasmid-encoded antigens have been reported by others (Portnoy and Martinez, 1985).

According to the nomenclature proposed by Bölin et al. (1985), the plasmid-specified major outer-membrane proteins of Yersinia (YOPs) should be designated YOP1-5. Most of the YOPs were detected with the whole-cell lysate used in the present study. The YOP1 of mol. wt 150000 was rarely seen in the immunoblot patterns with sera from most patients. However, the observed bands of mol. wt 52500 most probably represented subunits of YOP1, degraded by the denaturing conditions used (Skurnik et al., 1984). Likewise, the bands of mol. wts $\left(10^{3}\right) 45,34$ and 26 detected with several of our sera corresponded to YOPs 2, 4 and 5 , respectively. YOP3 of mol. wt 40000 was not detected with the human sera used in this study; nor was it detected with sera against $Y$. pestis in the study of Mazza et al. (1985) who, nevertheless, showed antibody responses to the antigens of mol. wts 26000 and 34000 . Thus, YOP3 is either poorly antigenic for man during natural infection or is denatured under the conditions used. The antigens of mol. wts $\left(10^{3}\right) 45,34$ and 26 also corresponded to the released proteins studied by Heesemann et al. (1984). Furthermore, it seems likely that the YOPs and the released proteins are identical antigens; whether they are integrated into the outer membrane or released to the surrounding medium apparently depends on the growth conditions used.

Antibody response against the plasmid-specified antigens, whether considered as the total number of bands observed or as bands in regions of different mol. wt, appeared quite similar in patients without post-infection arthritis and in those developing reactive arthritis after yersinia infection. Examination of individual bands, either encoded by the plasmid or otherwise expressed at $37^{\circ} \mathrm{C}$, revealed no clear differences between the two patient groups for any of the immunoglobulin classes studied. Special attention should be given, however, to the IgA-mediated recognition of bands of mol.wts $\left(10^{3}\right) 26,34$ and 52.5 because these bands were recognised almost exclusively in tests with sera from arthritic patients taken in the convalescent stage. These bands most probably represent the plasmid-encoded YOPs and the subunit of YOP1, as described by Bölin et al. (1985). The present findings, taken together with previous results (Toivanen et al., 1985), indicate that the differences in the antibody responses of non-arthritic and arthritic patients are quantitative rather than qualitative. The quantitative difference, particularly the strong and persisting $\operatorname{IgA}$ response as detected by ELISA, has been discussed previously (Granfors, 1979; Granfors et al., 1980 and 1983; Toivanen et al., 1985). 
The excellent technical assistance of Mrs S. Tuomola is greatly appreciated. We are grateful to Dr J. Heesemann, Hamburg, and Dr H. Wolf-Watz, Umeå, for fruitful discussions, and to $\mathbf{M r}$ L. Pulkkinen who provided the plasmid-free strain. This work was supported by grants from the US Public Health Service

\section{REFERENCES}

Bölin I, Portnoy D A, Wolf-Watz H 1985 Expression of the temperature-inducible outer membrane proteins of Yersiniae. Infection and Immunity 48:234-240.

Darveau R P, Charnetzky W T, Hurlbert R E, Hancock R E W 1983 Effects of growth temperature, 47-megadalton plasmid, and calcium deficiency on the outer membrane protein porin and lipopolysaccharide composition of Yersinia pestis EV76. Infection and Immunity 42: 1092-1101.

Granfors K 1979 Measurement of immunoglobulin M (IgM), $\mathrm{IgG}$, and IgA antibodies against Yersinia enterocolitica by enzyme-linked immunosorbent assay: persistence of serum antibodies during disease. Journal of Clinical Microbiology 9:336-341.

Granfors K, Isomäki H, von Essen R, Maatela J, Kalliomäki $J$ L, Toivanen A 1983 Yersinia antibodies in inflammatory joint diseases. Clinical and Experimental Rheumatology $1: 215-218$.

Granfors K, Viljanen M, Tiilikainen A, Toivanen A 1980 Persistence of IgM, IgG, and IgA antibodies to Yersinia in Yersinia arthritis. Journal of Infectious Diseases 141 :424429.

Hawkes R, Niday E, Gordon J 1982 A dot-immunobinding assay for monoclonal and other antibodies. Analytical Biochemistry 119: 142-147.

Heesemann J, Algermissen B, Laufs R 1984 Genetically manipulated virulence of Yersinia enterocolitica. Infection and Immunity 46: 105-110.

Heesemann J, Keller C, Morawa R, Schmidt N, Siemens H J, Laufs R 1983 Plasmids of human strains of Yersinia enterocolitica: molecular relatedness and possible importance for pathogenesis. Journal of Infectious Diseases 147: $107-115$.

Higuchi K, Smith J L 1961 Studies on the nutrition and physiology of Pasteurella pestis. VI. A differential plating medium for the estimation of the mutation rate to avirulence. Journal of Bacteriology 81 :605-608.

Kawaoka Y, Otsuki K, Tsubokura M 1983 Growth temperaturedependent variation in the bacteriophage-inactivating capacity and antigenicity of Yersinia enterocolitica lipopolysaccharide. Journal of General Microbiology 129:27392747.

Laemmli U K 1970 Cleavage of structural proteins during the assembly of the head of bacteriophage T4. Nature 227:680 685

Laird W J, Cavanaugh D C 1980 Correlation of autoagglutina- (grant no. 5 RO 1 AM 33311 awarded by the National Institute of Arthritis, Diabetes, and Digestive and Kidney Diseases) and the Sigrid Jusélius Foundation which are gratefully acknowledged.

tion and virulence of Yersiniae. Journal of Clinical Microbiology 11 : $430-432$

Martinez R J 1983 Plasmid-mediated and temperature-regulated surface properties of Yersinia enterocolitica. Infection and Immunity 41:921-930.

Mazigh D, Chalvignac M A, Quilici M L, Mollaret H H 1985 Lack of correlation between plasmid-encoded outer membrane proteins and virulence of Yersinia enterocolitica. Annales de L'Institut Pasteur (Microbiologie) 136B : 39-47.

Mazza G, Karu A E, Kingsbury D T 1985 Immune response to plasmid-and chromosome-encoded Yersinia antigens. Infection and Immunity 48:676-685.

Ogasawara M, Granfors K, Kono D H, Hill J L, Yu D T Y 1985 A Yersinia enterocolitica serotype O:3 lipopolysaccharidespecific monoclonal antibody reacts more strongly with bacteria cultured at room temperature than those cultured at $37^{\circ} \mathrm{C}$. Journal of Immunology 135:553-559.

Portnoy D A, Martinez R J 1985 Role of a plasmid in the pathogenicity of Yersinia species. Current Topics in Microbiology and Immunology 118:29-51.

Portnoy D A, Wolf-Watz H, Bölin I, Beeder A B, Falkow S 1984 Characterization of common virulence plasmids in Yersinia species and their role in the expression of outer membrane proteins. Infection and Immunity 43: 108-114.

Pulkkinen L, Granberg I, Granfors K, Toivanen A 1986 Restriction map of virulence plasmid in Yersinia enterocolitica O:3. Plasmid 16: 225-227.

Simonet M, Berche P, Mazigh D, Veron M 1985 Protection against Yersinia infection induced by non-virulence-plasmid-encoded antigens. Journal of Medical Microbiology 20:225-231.

Skurnik M 1985 Expression of antigens encoded by the virulence plasmid of Yersinia enterocolitica under different growth conditions. Infection and Immunity 47:183-190.

Skurnik M, Bölin I, Heikkinen H, Piha S, Wolf-Watz H 1984 Virulence plasmid-associated autoagglutination in Yersinia spp. Journal of Bacteriology 158: 1033-1036.

Toivanen A, Granfors K, Lahesmaa-Rantala R, Leino R, Ståhlberg T, Vuento R 1985 Pathogenesis of Yersiniatriggered reactive arthritis: Immunological, microbiological and clinical aspects. Immunological Reviews 86:47-70.

Towbin H, Staehelin T, Gordon J 1979 Electrophoretic transfer of proteins from polyacrylamide gels to nitrocellulose sheets: procedure and some applications. Proceedings of the National Academy of Sciences of the USA 76:4350-4354.

Zink D L et al. 1980 Plasmid-mediated tissue invasiveness in Yersinia enterocolitica. Nature 283:224-226. 